\title{
Analysis of Mercury Concentration in Honey from the Point of View of Human Body Exposure
}

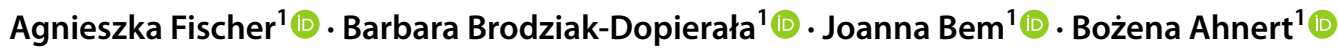

Received: 10 March 2021 / Accepted: 27 April 2021 / Published online: 6 June 2021

(c) The Author(s) 2021

\begin{abstract}
Honey is a highly valued product due to its nutritional value, pro-health and healing properties. Pollutants from the environment penetrate into nectar, honeydew, pollen and next into bee products and can cause human exposure after ingestion. Mercury $(\mathrm{Hg})$ is a toxic metal to living organisms. This is why it was important to determine the level of $\mathrm{Hg}$ in consumed honey. The aim of this manuscript is to analyse mercury concentration in honeys collected on the territory of Poland. A total of 108 samples of honey purchased in regional apiaries and hypermarkets were tested. The concentration of Hg was analysed in various types of honey (multifloral, honeydew, linden, goldenrod, acacia, buckwheat, rapeseed, sunflower, heather, dandelion, phacelia). The values of the Estimated Daily Intake (EDI), Estimated Weekly Intake (EWI) and \% Provisional Tolerable Weekly Intake (\% PTWI) were calculated. This allowed estimating the amount of $\mathrm{Hg}$ taken during consumption of the tested honeys.

The concentration of $\mathrm{Hg}$ ranged from 0.01 to $1.71 \mu \mathrm{g} / \mathrm{kg}$ and was $0.43 \mu \mathrm{g} / \mathrm{kg}$ on average. A higher concentration of $\mathrm{Hg}$, which was statistically significant, was recorded in honeydew honey, then in compound honeys. Honeys produced from one raw material had the lowest concentration of $\mathrm{Hg}$. There were no significant differences in the concentration of $\mathrm{Hg}$ depending on the origin of honey. The calculations have shown that consumption of a portion $(19 \mathrm{~g})$ of the tested honey per week is safe for both adults and children according to the applicable standards.
\end{abstract}

Keywords Honey $\cdot$ Mercury $\cdot$ AAS

\section{Introduction}

The development of the economy, in particular the industry, has contributed to an increase in the standard of human life, but also in environmental pollution by heavy metals [1]. Bees are exposed to different sources of contaminants through pollen and nectar that contain heavy metals of natural and anthropogenic origin. There are more and more reports of the possible contamination of honey and other bee products [2-5]. Mercury $(\mathrm{Hg})$ is a heavy metal listed among the top 10 contaminants [6]. When in a methylated form, its capacity to penetrate the biological barriers of the human organism is high [7]. It easily crosses the blood-brain barrier through LAT-type

Agnieszka Fischer

afischer@sum.edu.pl

1 Department of Toxicology and Bioanalysis, Faculty of Pharmaceutical Science, Medical University of Silesia, 30 Ostrogórska Str, 41-200 Sosnowiec, Poland amino acid transporters and its high affinity for lipid structures, the effects of which are accumulation in the brain and neurotoxicity $[8,9]$.

Honey is produced by honeybees (Apis mellifera L.) from nectars of flowers, from secretions of plant parts or from excreta of sucking insects [10,11]. Honey consists of simple sugars, mainly fructose and glucose (75\%), disaccharides, mainly sucrose (3-10\%), as well as other substances such as amino acids, vitamins $\left(\mathrm{A}, \mathrm{B}_{1}, \mathrm{~B}_{2}, \mathrm{~B}_{6}, \mathrm{~B}_{12}, \mathrm{C}\right)$, organic and inorganic acids, flavonoids and enzymes [12-14]. The final content of these compounds and honey composition depend on the type of nectar or honeydew that was collected to produce honey, the harvesting season, environmental factors and individual treatments used by beekeepers $[15,16]$.

Honey has an osmotic effect due to the high sugar content and low water content. It has a $\mathrm{pH}$ within the range of 3.2-4.5, which inhibits the development of pathogenic substances, and extends its shelf-life. This is also due to the production of hydrogen peroxide by the enzyme-glucose oxidase [15]. 
Honey has many valuable nutrients and has healing properties. Pro-health properties result from the contained minerals, microelements and trace elements, and these depend on the type of honey and the place of collection [17].

The most important mineral components of honey are the following oxides: $\mathrm{Na}, \mathrm{K}, \mathrm{Ca}$ and $\mathrm{P}$. The content of minerals in honey $(0.1-0.2 \%$ in nectar honey, $1 \%$ in honeydew) depends on soil conditions on which honey plants grew [14, 18]. Dark types of honey are characterised by a higher content of minerals $[14,19]$. Honey contains numerous micronutrients and trace elements: $\mathrm{Mg}, \mathrm{Si}, \mathrm{Pb}, \mathrm{Cd}, \mathrm{Cr}, \mathrm{Al}, \mathrm{B}, \mathrm{Sn}$, $\mathrm{Ag}, \mathrm{Ba}, \mathrm{As}, \mathrm{Mo}, \mathrm{Mn}, \mathrm{Co}$, Se and bioelements such as Fe, $\mathrm{Zn}$ and $\mathrm{Cu}$ [17, 20-22].

Apart from its nutritional properties, honey has antibacterial, antifungal and antiviral properties. The antibacterial activity depends on the presence of sugar, $\mathrm{pH}$, hydrogen peroxide and phytochemical components of honey [14, 23]. Honey may protect against gastrointestinal infection [14, 23, 24]. It is used to heal wounds, soothe inflammation and ulceration of the skin, and it supports treatment of infections, asthma and respiratory diseases [14, 23, 25, 26]. Studies have shown that topical application of honey can be effective in the treatment of seborrheic dermatitis and prevent hair loss $[14,27]$. Honey has an antimutagenic effect-it protects the bladder and breasts [28, 29]. Like propolis, it strengthens the immune system and reduces the risk of viral diseases $[28,30]$.

There is a close correlation between the accumulation of heavy metals in soil and plants and the content of heavy metals in bee products [31]. Hence, honey can be a useful environmental quality indicator within its collection area, which is about $7 \mathrm{~km}^{2}$ [14, 32]. Environmental pollutants can reach bee products from the air, water and soil [33, 34]. Therefore, research on determining the concentration of $\mathrm{Hg}$ in honey obtained from bees living in various environmental conditions is important.

The conducted research is the result of the growing interest in natural medicine and natural products of bee origin. As a natural product, honey is subject to the effects of environmental pollutants, including heavy metals. The aim of the study was to analyse the concentration of mercury in honeys purchased in Poland. Honey samples were taken from apiaries located throughout the country and contained variable environmental pollution. Thus, it was determined whether region of origin influences the concentration of $\mathrm{Hg}$ in honey. For comparison, the concentration of $\mathrm{Hg}$ in honeys purchased in hypermarkets, which did not contain precise information about the place of origin, was also tested. The amount of $\mathrm{Hg}$ in honey, depending on type, was tested. To determine the safety of honey consumption and potential human exposure, the values of daily and weekly $\mathrm{Hg}$ intake during the consumption of the tested honeys were calculated,
$\%$ Provisional Tolerable Weekly Intake (\% PTWI), and these values were referred to the acceptable standards.

\section{Material and Methods}

The subject of the research was 108 honey samples purchased in Poland in 2018-2020. The study analysed 11 types of honey (multifloral, honeydew, linden, goldenrod, acacia, buckwheat, rapeseed, sunflower, heather, dandelion, phacelia).

\section{Sampling}

The honey was purchased from individual sellers (regional apiaries) (Fig. 1) and in hypermarkets. Information on honey was read from the labels placed on the packaging. According to the information, the honey was obtained from various provinces covering the entire territory of Poland; it was also prepared by producers from blends of honeys from the territory of the European Union and from countries not in the European Union.

\section{Determination}

The concentration of $\mathrm{Hg}$ was determined in the honey samples using the AMA 254 analyser (Altec, Czech Republic). Measurement conditions were wavelength-253.65 nm, carrier gas - technical oxygen and inlet pressure-200-250 kPa. Specific intervals for the analysis process were used (s): 120 (drying), 140 (decomposition) and 60 (detection) [17, 18]. The limit of detection (LOD) $=0.001 \mathrm{ng} \mathrm{Hg}$; limit of

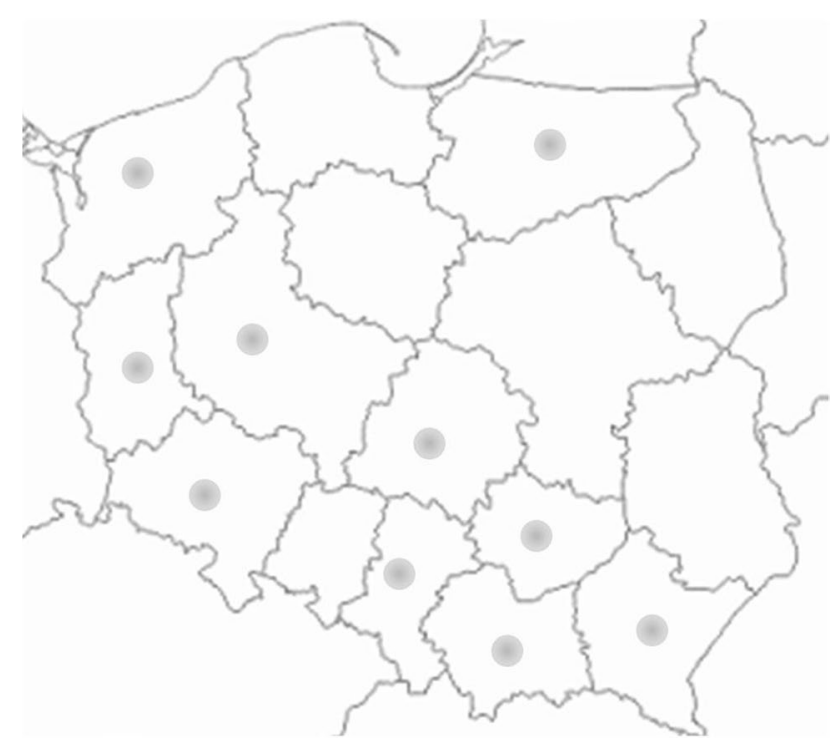

Fig. 1 The area of Poland divided into provinces with the location of apiaries. The location of the apiaries where the honey for research was collected 
quantitation $(\mathrm{LOQ})=0.005 \mathrm{ng} \mathrm{Hg}$. The measurement concerned the total amount of $\mathrm{Hg}$, regardless of its form in the sample. The AMA 254 analyser does not require sample preparation before determination. The samples for analysis (average weight $=0.10393 \mathrm{~g}$ ) were weighed on an analytical balance (RADWAG, Poland). Three independent test samples were prepared from each honey. The concentration of $\mathrm{Hg}$ in the honey sample was the arithmetic mean of 3 measurements.

Validation of designations was checked using reference material (INCT-MPH-2 Mixed Polish Herbs). The Hg concentration in reference material, measured: $n=5$, was 0.0154-0.0175 $\mu \mathrm{g} \mathrm{Hg} / \mathrm{g}$ (mean 0.0166 $\pm 0.0001 \mu \mathrm{g} \mathrm{Hg} / \mathrm{g}$ ).

\section{Statistical Analysis}

The concentration of $\mathrm{Hg}$ in honey samples was made using the Statistica ver. 13 (StatSoft, Poland). The normality of the distribution was checked using the Shapiro-Wilk test. As the concentration of $\mathrm{Hg}$ in the analysed samples differed from a normal distribution, the statistical significance and its level were checked with the Mann-Whitney U test (for two samples) and the Kruskal-Wallis $\mathrm{H}$ test (for a greater number of samples). The value of $p<0.05$ was considered statistically significant.

\section{Risk Calculations}

The safety of honey consumption by children and adults was analysed on the basis of the \% Provisional Tolerable Weekly Intake (\% PTWI) value, which was calculated in relation to the acceptable level [35]. These values for adults are $1 \mu \mathrm{g} / \mathrm{kg}$ bw per week and for children $4 \mu \mathrm{g} / \mathrm{kg}$ bw per week. The average daily honey consumption was set at $19 \mathrm{~g}$ $[36,37]$. The average weight for adults was $70 \mathrm{~kg}$ and for children $-15 \mathrm{~kg}$. The Estimated Daily Intake (EDI) and the
Estimated Weekly Intake (EWI) of $\mathrm{Hg}$ and \% Provisional Tolerable Weekly Intake (\% PTWI) were calculated using the following formulas, in accordance with [37, 38]:

$\mathrm{EDI}=\frac{\text { mean daily consumption of honey } \times \text { metal level }}{\text { body weight }}$

where:

EDI-Estimated Daily Intake

EWI-Estimated Daily Intake $\times 7$

EWI-Estimated Weekly Intake

$\%$ PTWI $=\frac{\text { Estimated Weekly Intake } \mathrm{Cd} \times 100}{\text { PTWI }}$

where \% PTWI—\% Provisional Tolerable Weekly Intake.

\section{Results}

The statistical analysis of concentration of $\mathrm{Hg}$ in samples of various types of honey is presented in Table 1 . The concentration of $\mathrm{Hg}$ in the tested honeys ranged from 0.01 to $1.71 \mu \mathrm{g} /$ $\mathrm{kg}$ and was $0.43 \mu \mathrm{g} / \mathrm{kg}$ on average. The coefficient of variation amounting to $96.4 \%$ proves that there is a high variability of $\mathrm{Hg}$ concentration in the tested samples. The greatest number of honeys $(n=30)$ was the multifloral type. The average concentration of $\mathrm{Hg}$ in multifloral honey (median $0.33 \mu \mathrm{g} / \mathrm{kg}$ ) was characterised by a high coefficient of variation (98.2\%). The highest maximum concentration of $\mathrm{Hg}$ among all analysed types of honey was found in multifloral honey $(1.70 \mu \mathrm{g} /$ $\mathrm{kg}$ ). The sample with the greatest concentration of $\mathrm{Hg}$ was purchased in the apiary of a local producer from the province of Lesser Poland (Southern Poland). The most similar results of the concentration of $\mathrm{Hg}$ in the samples were found for phacelia honey (coefficient of variation-51.0\%). In relation
Table 1 Statistical analysis of the concentration of $\mathrm{Hg}$ in various types of honey $(\mu \mathrm{g} / \mathrm{kg})$

\begin{tabular}{|c|c|c|c|c|c|c|c|c|c|c|}
\hline \multirow[t]{2}{*}{ Type of honey } & \multirow[t]{2}{*}{$n$} & \multirow[t]{2}{*}{$\mathrm{AM}$} & \multirow[t]{2}{*}{ Range } & \multirow[t]{2}{*}{ SD } & \multirow[t]{2}{*}{$\mathrm{Me}$} & \multicolumn{4}{|c|}{ Percentile } & \multirow[t]{2}{*}{ CV\% } \\
\hline & & & & & & 10 & 25 & 75 & 90 & \\
\hline All honey & 108 & 0.43 & $0.01-1.71$ & 0.41 & 0.31 & 0.06 & 0.13 & 0.60 & 1.08 & 96.4 \\
\hline Acacia & 10 & 0.41 & $0.01-1.03$ & 0.32 & 0.35 & 0.03 & 0.18 & 0.69 & 0.88 & 79.4 \\
\hline Phacelia & 4 & 0.36 & $0.11-0.52$ & 0.18 & 0.41 & 0.11 & 0.23 & 0.49 & 0.52 & 51.0 \\
\hline Buckwheat & 15 & 0.28 & $0.07-1.11$ & 0.28 & 0.15 & 0.07 & 0.10 & 0.35 & 0.62 & 99.7 \\
\hline Linden & 15 & 0.35 & $0.01-0.97$ & 0.28 & 0.31 & 0.01 & 0.10 & 0.55 & 0.70 & 80.3 \\
\hline Dandelion & 2 & 0.12 & $0.03-0.22$ & 0.13 & 0.12 & 0.03 & 0.03 & 0.22 & 0.22 & 107 \\
\hline Goldenrod & 5 & 0.36 & $0.02-1.30$ & 0.54 & 0.09 & 0.02 & 0.04 & 0.34 & 1.30 & 152 \\
\hline Rapeseed & 10 & 0.25 & $0.01-0.71$ & 0.20 & 0.22 & 0.02 & 0.16 & 0.32 & 0.56 & 81.2 \\
\hline Sunflower & 2 & 0.27 & $0.10-0.44$ & 0.24 & 0.27 & 0.10 & 0.10 & 0.44 & 0.44 & 89.7 \\
\hline Honeydew & 13 & 0.72 & $0.07-1.55$ & 0.46 & 0.71 & 0.11 & 0.36 & 0.93 & 1.30 & 64.3 \\
\hline Multifloral & 30 & 0.54 & $0.06-1.71$ & 0.53 & 0.33 & 0.08 & 0.17 & 0.74 & 1.55 & 98.2 \\
\hline Heather & 2 & 0.29 & $0.11-0.47$ & 0.26 & 0.29 & 0.11 & 0.11 & 0.47 & 0.47 & 89.4 \\
\hline
\end{tabular}

$A M$, arithmetic mean; $S D$, standard deviation; $M e$, median; $C V$, coefficient of variation 
to the type of honey, the highest average concentration of $\mathrm{Hg}$ was recorded in honeydew honeys (median $0.71 \mu \mathrm{g}$ / $\mathrm{kg}$ ), the lowest in dandelion honeys (median- $0.12 \mu \mathrm{g} / \mathrm{kg}$ ), but the number of samples of this type was limited $(n=2)$. The relatively low concentration of $\mathrm{Hg}$ was also recorded in buckwheat honey $(n=15$, median $0.15 \mu \mathrm{g} / \mathrm{kg})$ and goldenrod honey ( $n=5$, median $0.09 \mu \mathrm{g} / \mathrm{kg}$ ). The honeys, depending on the type and value of the median of $\mathrm{Hg}$ (increasing), are as follows: goldenrod, dandelion, buckwheat, rapeseed, sunflower, heather, linden, multifloral, acacia, phacelia and honeydew. LOQ of $\mathrm{Hg}$ in various types of honey (multifloral, honeydew, linden, goldenrod, acacia, buckwheat, rapeseed, sunflower, heather, dandelion, phacelia) was not statistically significant ( $p=0.18$, Kruskal-Wallis H test).

The tested honey samples were grouped according to their composition into multi-component, single-component and honeydew honey. Statistically significant differences were found in the concentration of $\mathrm{Hg}$ depending on the composition of honey (single-component, multi-component and honeydew) ( $p=0.01$, Kruskal-Wallis $\mathrm{H}$ test). The highest concentration of $\mathrm{Hg}$ was found in honeydew honeys (median $0.71 \mu \mathrm{g} / \mathrm{kg}$ ) - more than twice as high as in multi-component honeys (median $0.32 \mu \mathrm{g} / \mathrm{kg}$ ) and three times higher than in single-component honeys (median $0.26 \mu \mathrm{g} / \mathrm{kg}$ ) (Fig. 2).

The analysed honeys were purchased in hypermarkets and apiaries. The average concentration of $\mathrm{Hg}$ was higher in honeys purchased in hypermarkets than in regional apiaries (median, respectively: $0.30 \mu \mathrm{g} / \mathrm{kg}$ and $0.36 \mu \mathrm{g} / \mathrm{kg}$ ); these differences were not statistically significant $(p=0.12$, Mann-Whitney U test) (Fig. 3). The honeys purchased in stores contained information that their place of origin was the EU and non-EU countries. The measurement of the concentration of $\mathrm{Hg}$ in honey depending on the location in Poland did not show statistically significant differences as well. Honey samples from the Silesian Province, which

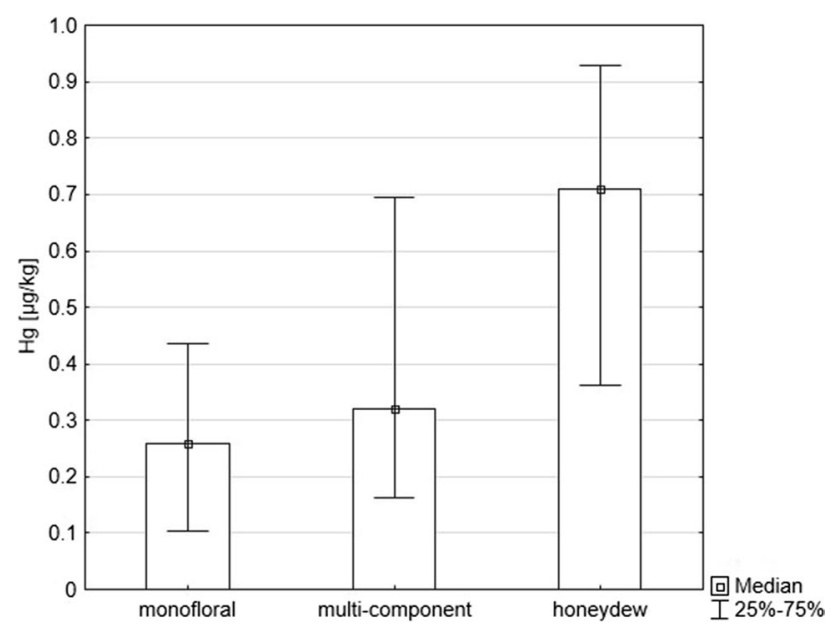

Fig. 2 Comparison of the concentration of $\mathrm{Hg}$ in single-component (monofloral), multi-component (polyfloral) and honeydew honeys

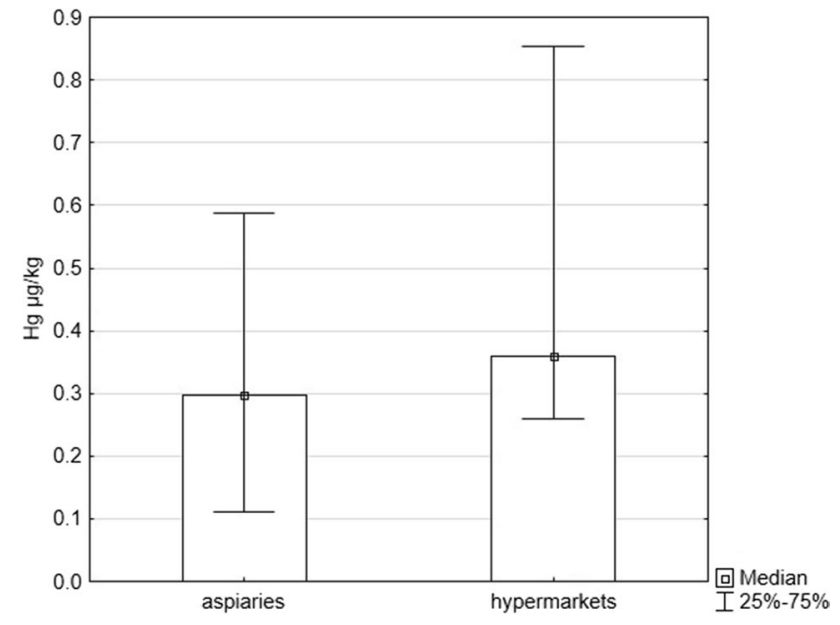

Fig. 3 Comparison of the concentration of $\mathrm{Hg}$ in honeys bought in hypermarkets and apiaries

is the most industrialised and highly urbanised region of Poland, had a lower $\mathrm{Hg}$ concentration than in other regions (Fig. 4) ( $p=0.877$, Mann-Whitney U test).

Table 2 shows the calculated values of EDI, EWI and \% PTWI. The consumption of $19 \mathrm{~g}$ of honey per week is safe for human health, as it results in Hg intake at the level of $0.009-0.020 \%$ PTWI for adults and $0.010-0.023 \%$ PTWI for children.

\section{Discussion}

As a component of a daily diet, natural products are now more and more valued and desired. There is also a belief that natural products are healthy and safe. Honey has a

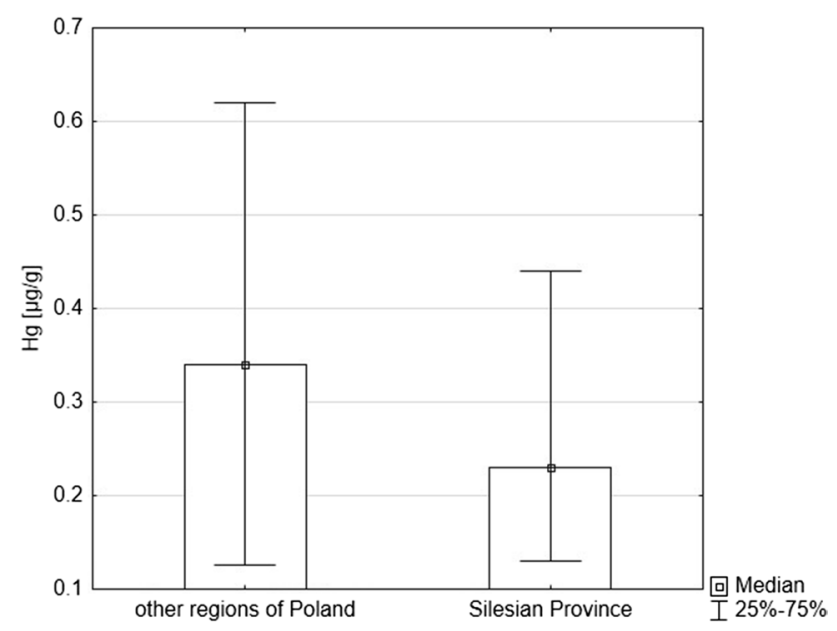

Fig. 4 Comparison of the concentration of $\mathrm{Hg}$ in honeys from the Silesian Province* and other regions of Poland. *Silesian Province is the most industrialized and highly urbanized region of Poland 


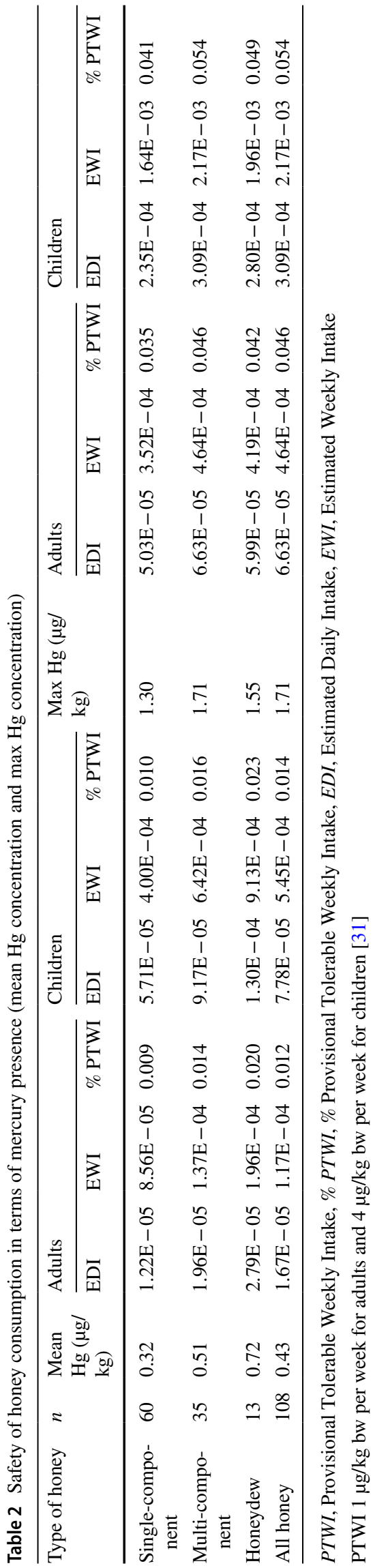

pro-health effect that is used in natural medicine and is also valued for its taste. It can be used as an auxiliary in the treatment of many diseases, including the upper respiratory tract, cardiovascular system, gastrointestinal tract and urinary system [23-30]. The effect of honey depends on the raw material from which it is made. The most important effects were anti-inflammatory, antibacterial, antiviral and antifungal. What is more, honey is easily available, both in grocery stores, herbal stores, pharmacies or directly in apiaries. Despite its beneficial effects, honey may contain environmental pollutants, e.g. heavy metals, including $\mathrm{Hg}$. Mercury is absorbed by plants along with water and minerals. Pollen and honeydew obtained from plants are used by bees to produce honey, which is why bee products may contain $\mathrm{Hg}$ compounds.

The maximum concentration of $\mathrm{Hg}$ in honey specified in the EU Commission Regulation 2018/73 of 16 January 2018 that amended Annexes II and III to Regulation (EC) No 396/2005 of the European Parliament and of the Council is $0.01 \mathrm{mg} / \mathrm{kg}$ [39]. The average concentration of $\mathrm{Hg}$ determined in the tested honeys $(0.43 \mu \mathrm{g} / \mathrm{kg})$ did not exceed the acceptable standards in any of the analysed samples. Also, the maximum concentration of $\mathrm{Hg}$ determined in the honey samples $(1.71 \mu \mathrm{g} / \mathrm{kg})$ did not exceed the above-mentioned normative values.

Madras-Majewska et al. conducted similar research in Poland [40]. The concentration of $\mathrm{Hg}$ in honeys from the apiaries was $0.27 \mu \mathrm{g} / \mathrm{kg}$ and was similar to the values obtained in our own research. In the studies by Dżugan et al. [41], carried out in Poland as well, but covering only a selected area (South-Eastern Poland, Sub-Carpathian Province), the concentration of $\mathrm{Hg}$ in honey and in organisms of bees, determined using the ICP-OES method, was below the limit of quantification $(<1 \mu \mathrm{g} / \mathrm{g})$.

In the research from the territory of Italy (8 provinces) [10], the concentration of $\mathrm{Hg}$ was at a similar level as in the authors' own research. The average concentration of $\mathrm{Hg}$ was $0.19 \mu \mathrm{g} / \mathrm{kg}$, and the range of changes was $0.04-1.46 \mu \mathrm{g} / \mathrm{kg}$, similar to our research $(0.01-1.71 \mu \mathrm{g} / \mathrm{kg})$. Other research from the same country showed that the concentration of $\mathrm{Hg}$ was $0.007 \mu \mathrm{g} / \mathrm{g}$ [42], which was much lower.

The analysis of honey for $\mathrm{Hg}$ concentration in another European country, the Czech Republic, showed slightly higher values in relation to our own research: $0.67-2.93 \mu \mathrm{g} / \mathrm{kg}$ [43].

Toth et al. [44] studied the content of $\mathrm{Hg}$ in honeys from eastern Slovakia. Honey from the city of Košice had $0.081 \mu \mathrm{g} \mathrm{Hg} / \mathrm{kg}$, and honey from the rural areas of Rozhanovce had $0.079 \mu \mathrm{g} \mathrm{Hg} / \mathrm{kg}$. No statistically significant differences were found between the concentration of $\mathrm{Hg}$ in honeys from urban and rural areas.

A comparison of $\mathrm{Hg}$ content in honeys from rural and urban areas was also made by Maggid et al. [33]. The average 
level of $\mathrm{Hg}$ in rural honeys in Tanzania was $11.910 \mu \mathrm{g} / \mathrm{kg}$ and from London-7.023 $\mu \mathrm{g} / \mathrm{kg}$. A reverse relation was described by Toporcák et al. [45] when examining honey samples from Slovakia. The concentration of $\mathrm{Hg}$ for honeys obtained from polluted areas was in the range of 50-212 $\mu \mathrm{g} /$ $\mathrm{kg}$, while from non-polluted areas it was many times lower (1-3 $\mu \mathrm{g} / \mathrm{kg})$. Our research showed no statistically significant differences in the concentration of $\mathrm{Hg}$ depending on the origin of honey. Moreover, honeys from the industrial region (Silesian Province) had a lower concentration of $\mathrm{Hg}$ than from other areas in Poland.

The comparison of the results based on literature data shows a different level of $\mathrm{Hg}$ concentration in honeys. These differences are clearly visible in relation to the geographical origin of honey in different countries.

Honeys from Greece had the $\mathrm{Hg}$ concentration lower than $50 \mu \mathrm{g} / \mathrm{kg}$ [46], similar to the research by Toporcák et al. [45] from industrial areas in Slovakia, where these values were much higher than in the authors' own research. Similar results were in the studies by Akbari et al. [47] in honey from Iran, where the $\mathrm{Hg}$ concentration was as high as $3.03 \mathrm{mg} / \mathrm{kg}$. The studies by Bilandzic et al. [13] conducted in Croatia showed that the average $\mathrm{Hg}$ concentration was higher-2.72 $\mu \mathrm{g} / \mathrm{kg}$.

The research by Jovetić et al. [48] determined the concentration of $\mathrm{Hg}$ in honeys from the city of Belgrade. The obtained results were significantly higher than in the authors' own research and ranged between 73 and $519 \mu \mathrm{g} / \mathrm{kg}$ [48]. Scientists explain that the increased level of $\mathrm{Hg}$ is due to anthropogenic sources of air pollution, especially combustion of fossil fuels, which are still used for heating in many houses in the Zemun district of Belgrade [48].

What is more, a high average $\mathrm{Hg}$ concentration in honey in relation to our research was found in Nigeria [49], Libya [50] and Malaysia [51]. However, the concentration of $\mathrm{Hg}$ in honey, researched by Indian scientists, was determined to be below the apparatus' detection level [52].

Our research included a comparison of the concentration of $\mathrm{Hg}$ in honeys from different places of purchase. Although, the concentration of $\mathrm{Hg}$ in honeys from hypermarkets was higher than in products purchased directly from producers (in apiaries), these differences were not statistically significant. This analysis also included a product comparison in terms of the origin of ingredients. Honey bought in hypermarkets was generally defined by producers (without specified place of origin) as a mixture of honeys from EU and non-EU countries. In this case, there were no statistically significant differences in the concentration of $\mathrm{Hg}$ in honey as well.

In the case of $\mathrm{Hg}$ concentration in different types of honey, reference can be made to the studies by $\mathrm{Ru}$ et al. [53] from China. Although, the results of the concentration of $\mathrm{Hg}$ in these studies were significantly different from ours (they were several times higher), they indicate that the concentration of Hg may vary depending on the plant raw material from which honey is produced. For comparison, the average $\mathrm{Hg}$ concentration in acacia honey was $2.51 \mu \mathrm{g} /$ $\mathrm{kg}$, in linden honey $-4.00 \mu \mathrm{g} / \mathrm{kg}$ and in multifloral honey$2.23 \mu \mathrm{g} / \mathrm{kg}$ [53] (respectively in our research: $0.41,0.35$ and $0.54 \mu \mathrm{g} \mathrm{Hg} / \mathrm{kg}$ ). The highest concentration of $\mathrm{Hg}$ was found in linden honey $(4.00 \mu \mathrm{g} / \mathrm{kg})$ and the lowest in honey obtained from Chinese jujube $(0.34 \mu \mathrm{g} / \mathrm{kg})$ [53]. In our research, honeydew honey contained the highest amounts of $\mathrm{Hg}(0.72 \mu \mathrm{g} / \mathrm{kg})$ and dandelion honey the lowest $(0.12 \mu \mathrm{g} /$ $\mathrm{kg}$ ).

Research of different types of honey from the KoprivnicaKriżevci agricultural region in Croatia [54] showed that multifloral honeys had a statistically significant $(p<0.01)$ content of $\mathrm{Hg}(1.35 \mathrm{mg} / \mathrm{kg})$ which acacia honeys did not $(0.46 \mathrm{mg} / \mathrm{kg})$. Similarly, in our research, the concentration of $\mathrm{Hg}$ was statistically much higher in multi-component honeys than in single-component honeys.

Whereas, in the honey obtained by Tariba Lovaković et al. [55] in Southern Croatia, significantly lower Hg values were found compared to the agricultural region of KoprivnicaKriżevci. In this research, the average content of $\mathrm{Hg}$ in linden honey was comparable to our research and amounted to $0.33 \mu \mathrm{g} / \mathrm{kg}$, slightly lower in acacia honey- $0.34 \mu \mathrm{g} / \mathrm{kg}$ and in sunflower honey slightly higher $-0.43 \mu \mathrm{g} / \mathrm{kg}$ (in our research $-0.27 \mu \mathrm{g} / \mathrm{kg}$ ) [55]. For comparison, the average concentration of $\mathrm{Hg}$ in fir honeydew honey was $1.38 \mu \mathrm{g} /$ $\mathrm{kg}$ and in oak honeydew honey-0.99 $\mu \mathrm{g} / \mathrm{kg}$ [55] and was higher than in the honeydew honey we tested $-0.72 \mu \mathrm{g} / \mathrm{kg}$.

Differences in the concentration of $\mathrm{Hg}$ in particular types of honey we examined were not statistically significant $(p>0.05)$. The highest concentration of $\mathrm{Hg}$ was found in honeydew and multi-component honey. However, it was shown that the concentration of $\mathrm{Hg}$ in the samples of honeys obtained from one plant (monofloral) was statistically significantly lower than that of multi-component honeys. Similar results were found in the studies by Winiarska-Mieczan et al. [37] where multi-component honeys contained higher amounts of heavy metals $(\mathrm{Cd}$ and $\mathrm{Pb})$ than single-component honeys.

Based on the obtained results, the amount of $\mathrm{Hg}$ ingested into the body during daily and weekly honey consumption was calculated. The assumption was a weekly consumption of $19 \mathrm{~g}$ of honey [36]. The tested honey samples provide the human body with an amount of $\mathrm{Hg}$ which is $0.012 \%$ PTWI in adults and $0.014 \%$ PTWI in children. Thus, the permissible norms of $\mathrm{Hg}$ consumption were not exceeded in any of the tested honeys [35]. The mean weekly consumption of $\mathrm{Hg}$ ranged from 1.17 to $9.13 \mathrm{E}-04 \mu \mathrm{g} / \mathrm{bw} / \mathrm{week}$. In the research by Maggid et al. [33], the weekly consumption of $\mathrm{Hg}$ found in honey was much higher $(15.98 \mu \mathrm{g} /$ person/week); however, in our research the average consumption of honey was $19 \mathrm{~g}$ per week, and in the research by Maggid et al. [33] it was 
$316 \mathrm{~g}$. For comparison, EWI values resulting from the consumption of honey from the territory of Poland, calculated for $\mathrm{Cd}$ and $\mathrm{Pb}$, were also low-6.91E - 06 and 5.32E $-05 \mathrm{mg}$, respectively [37].

Summing the obtained results up, none of the tested honeys was found to contain $\mathrm{Hg}$ exceeding the permissible value. However, the dynamic development of the industry creates a certain risk. The amount of contamination in honey and other products produced by bees may increase. For example, Madras-Majewska et al. [40] examined the concentration of $\mathrm{Hg}$ in bee pollen from various regions of Poland. The range of changes was $0.18-7.59 \mu \mathrm{g} \mathrm{Hg} / \mathrm{kg}$, and the highest concentration of $\mathrm{Hg}$ was found in pollen from Northern Poland (West Pomeranian Province-2.28 $\mu \mathrm{g} / \mathrm{kg}$ ). To ensure the appropriate quality of bee products, which are often used for medicinal purposes, it is advisable to conduct tests for the concentration of $\mathrm{Hg}$ and other heavy metals.

\section{Conclusions}

The concentration of $\mathrm{Hg}$ in the tested honeys bought in Poland varied greatly. Depending on the type of honey, the concentration of $\mathrm{Hg}$ increased as follows: goldenrod, dandelion, buckwheat, rapeseed, sunflower, heather, linden, multifloral, acacia, phacelia and honeydew. Differences in the concentration of $\mathrm{Hg}$, depending on the type of honey, were not statistically significant. Whereas, the comparison of honeydew, multi-component and single-component honeys showed a statistically significant higher concentration of $\mathrm{Hg}$ in honeydew and multi-component honeys. The lowest concentration of $\mathrm{Hg}$ was found in single-component honeys. The origin of product used to produce honey did not statistically affect the concentration of $\mathrm{Hg}$ in the tested honey samples. Honey from apiaries located in Poland did not differ statistically in terms of mercury content. Products purchased in apiaries and hypermarkets did not differ statistically in terms of the concentration of $\mathrm{Hg}$. The calculated values of EDI, EWI and \% PTWI have shown that consumption of a portion ( $19 \mathrm{~g})$ of the tested honey per week is safe for both adults and children according to the applicable standards. This concerns the indices calculated for both the average and the maximum concentration of $\mathrm{Hg}$.

Open Access This article is licensed under a Creative Commons Attribution 4.0 International License, which permits use, sharing, adaptation, distribution and reproduction in any medium or format, as long as you give appropriate credit to the original author(s) and the source, provide a link to the Creative Commons licence, and indicate if changes were made. The images or other third party material in this article are included in the article's Creative Commons licence, unless indicated otherwise in a credit line to the material. If material is not included in the article's Creative Commons licence and your intended use is not permitted by statutory regulation or exceeds the permitted use, you will need to obtain permission directly from the copyright holder. To view a copy of this licence, visit http://creativecommons.org/licenses/by/4.0/.

\section{References}

1. Cyran M (2013) Effect of environmental exposure to mercury on the functioning of the human body. Environ Med 16:55-58 ((in Polish))

2. Ćirić J, Đorđević V, Trbović D, Baltić T, BrankovićLazić I, Matović K, Janković S, Parunović N (2020) Risk assessment of toxic elements in acacia honey. Meat Technol 61:70-74. https:// doi.org/10.18485/meattech.2020.61.1.6

3. Ćirić J, Spirić D, Baltić T, Branković Lazić I, Trbović D, Parunović N, Petronijević R, Đorđević V (2020) Honey bees and their products as indicators of environmental element deposition. Biol Trace Elem Res. https://doi.org/10.1007/ s12011-020-02321-6

4. Ćirić J, Spirić D, Baltić T, Janjić J, Petronijević R, Simunović S, Djordjević V (2019) Element concentration and fatty acid composition of Serbian bee bread. In IOP conference. Series: Environ Earth Sci 333:012050. https://doi.org/10.1088/17551315/333/1/012050

5. Spirić D, Ćirić J, Đorđević V, Nikolić D, Janković S, Nikolić A, Petrović Z, Katanić N, Teodorović V (2019) Toxic and essential element concentrations in different honey types. Int J Environ Anal Chem 99:474-485. https://doi.org/10.1080/03067319. 2019.1593972

6. Zhou F, Yin G, Gao Y, Liu D, Xie J, Ouyang L, Fan Y, Yu H, Zha Z, Wang K, Shao L, Feng Ch, Fan G (2019) Toxicity assessment due to prenatal and lactational exposure to lead, cadmium and mercury mixtures. Environ Int 133:105192

7. Klassen CD, Watkins JB (2015) Casarett and Doull Casarett \& Doull's essentials of toxicology. Third Edition, McGraw-Hill Education-Europe

8. Creed JH, Peeri NC, Anic GM, Thompson RC, Olson JJ, LaRocca RV, Chowdhary SA, Brockman JD, Gerke TA, Nabors LB, Egan K (2019) Methylmercury exposure, genetic variation in metabolic enzymes, and the risk of glioma. Sci Rep 9:10861

9. Aragão WAB, Teixeira FB, Fagundes NCF, Fernandes RM, Fernandes LMP, da Silva MCF, Amado LL, Sagica FES, Oliveira EHC, Crespo-Lopez ME, Maia CSF, Lima RR (2018) Hippocampal dysfunction provoked by mercury chloride exposure: evaluation of cognitive impairment. Oxid Med Cell Longev 11:7878050

10. Quinto M, Miedico O, Spadaccino G, Paglia G, Mangiacotti M, Li D, Centonze D, Chiaravalle AE (2016) Characterization, chemometric evaluation, and human health-related aspects of essentials and toxic elements in Italian honey samales by inductively coupled plasma mass spectrometry. Environ Sci Pollut Res Int 23:25374-25384

11. Directive C (2002) 2001/110/EC of 20 December 2001 relating to honey. Off J Eur Union 10:47-55

12. Altundag H, Bina E, Altintig E (2016) The levels of trace elements in honey and molasses samples that were determined by ICP-OES after microwave digestion method. Biol Trace Elem Res 170:508-514

13. Bilandzic N, Dokic M, Sedak M, Kolanovic BS, Varenina I, Koncurat A, Rudan N (2011) Determination of trace elements in of Croatian floral honey originating from different regions. Food Chem 128:1160-1164

14. Czipa N, Andrási D, Kovács B (2015) Determination of essential and toxic elements in Hungarian honeys. Food Chem 175:536-542 
15. Ratiu IA, Al-Suod H, Bukowska M, Ligor M, Buszewski B (2019) Correlation study of honey regarding their physicochemical properties and sugars and cyclitols content. Molecules 25:34

16. Altun SK, Dinç H, Paksoy N, Temamoğullari FK, Savrunlu M (2017) Analyses of mineral content and heavy metal of honey samples from south and east region of Turkey by using ICP-MS. Int J Anal Chem 2017:6 pages

17. Madejczyk M, Baralkiewicz D (2008) Characterization of Polish rape and honeydew honey according to their mineral contents using ICP-MS and F-AAS/AES. Anal Chim Acta 617:11-17

18. Hernández OM, Fraga JMG, Jiménez AI, Jiménez F, Arias JJ (2005) Characterization of honey from the Canary Islands: determination of the mineral content by atomic absorption spectrophotometry. Food Chem 93:449-458

19. Lachman J, Kolihová D, Miholová D, Košata J, Titera D, Kult K (2007) Analysis of minority honey components: possible use for the evaluation of honey quality. Food Chem 101:973-979

20. Nikolic TV, Kojic D, Orcic S, Batinic D, Vukasinovic E, Blagojevic DP, Purac J (2016) The impact of sublethal concentrations of $\mathrm{Cu}, \mathrm{Pb}$ and $\mathrm{Cd}$ on honey bee redox status, superoxide dismutase and catalase in laboratory conditions. Chemosphere 164:98-105

21. Hossain MA, Piyatida P, da Silva JAT, Fujita M (2012) Molecular mechanism of heavy metal toxicity and tolerance in plants: central role of glutathione in detoxification of reactive oxygen species and methylglyoxal and in heavy metal chelation. J Bot 2012:1-37

22. Tchounwou PB, Yedjou CG, PatlollaAK SDJ (2012) Heavy metal toxicity and the environment. EXS 101:133-164

23. Eteraf-Oskouei T, Najafi M (2013) Traditional and modern uses of natural honey in human diseases: a review. Iran J Basic Med Sci 16:731-742

24. Alnaqdy A, Al-Jabri A, Al Marhrooqi Z, Nzeako B, Nsanze H (2005) Inhibition effect of honey on the adherence of Salmonella to intestinal epithelial cells in vitro. Int J Food Microbiol 103:347-351

25. Basualdo C, Sgroy V, Finola SM, Marioli MJ (2007) Comparison of the antibacterial activity of honey from different provenance against bacteria usually isolated from skin wounds. Vet Microbiol 124:375-381

26. Bogdanov S, Jurendic T, Sieber R, Gallmann P (2009) Honey for nutrition and health: a review. J Am Coll Nutr 27:677-689

27. Al-Waili NS (2001) Therapeutic and prophylactic effects of crude honey on chronic seborrheic dermatitis and dandruff. Eur J Med Res 6:306-308

28. Grembecka M, Szefer P (2013) Evaluation of honeys and bee products quality based on their mineral composition using multivariate techniques. Environ Monit Assess 185:4033-4047

29. Alvarez-Suarez JM, Tulipani S, Romandini S, Bertoli E, Battino M (2010) Contribution of honey in nutrition and human health: a review. Med J Nutrition Metab 3:15-23

30. Xu Y, Luo L, Chen B, Fu F (2009) Recent development of chemical components in propolis. Front Biol 4:385-391

31. Roman A, Madras-Majewska B, Popiela-Pleban E (2011) Comparative study of selected toxic elements in propolis and honey. J Apic Sci 55:97-106

32. Almeida-Silva M, Canha N, Galinha C, Dung HM, Freitas MC, Sitoe T (2011) Trace elements in wild and orchard honeys. Appl Radiat and Isot 69:1592-1595

33. Maggid AD, Kimanya ME, Ndakidemi PA (2014) The contamination and exposure of mercury in honey from Singida, Central Tanzania. Am J Res Commun 2:127-139

34. Bogdanov S (2006) Contaminants of bee products. Apidologie 37:1-18

35. Joint FAO/WHO Expert Committee on Food Additives and WHO Organization (2011) Evaluation of certain food additives and contaminants: seventy-third [73rd] report of the Joint FAO/
WHO Expert Committee on Food Additives. https://apps.who. int/iris/handle/10665/44515. Accessed 1 Mar 2021

36. Żak N (2017) Consumer preferences for the Polish and USA consumption of honey. Sci J Market Manag 2:117-130. https:// doi.org/10.18276/miz.2017.48-11

37. Winiarska-Mieczan A, Wargocka B, Jachimowicz K, Baranowska-Wójcik EK, K, Kwiecień M, (2021) Evaluation of consumer safety of Polish honey the content of $\mathrm{Cd}$ and $\mathrm{Pb}$ in multifloral, monofloral and honeydew honeys. Biol Trace Elem Res. https:// doi.org/10.1007/s12011-020-02535-8

38. Winiarska-Mieczan A, Kwiecień M (2016) The effect of exposure to $\mathrm{Cd}$ and $\mathrm{Pb}$ in the form of a drinking water or feed on the accumulation and distribution of these metals in the organs of growing Wistar rats. Biol Trace Elem Res 22:230-236. https:// doi.org/10.1007/s12011-015-0414-4

39. Commission Regulation (EU) 2018/73 of 16 January 2018 amending Annexes II and III to Regulation (EC) No 396/2005 of the European Parliament and of the Council as regards maximum residue levels for mercury compounds in or on certain products. Accessed 1 Mar 2021

40. Madras-Majewska B, Jasiński Z, Zajdel B, Gąbka J, Ochnio M, Petryka W, Kamiński Z, Ścięgosz J (2014) Content of selected toxic elements in bee products. Animal Production Review 82:49-51 ((in Polish))

41. Dżugan M, Wesołowska M, Zaguła G, Kaczmarski M, Czernicka M, Puchalski C (2018) Honeybees (Apis mellifera) as a biological barrier for contamination of honey by environmental toxic metals. Environ Monit Assess 190:101

42. Meli MA, Desideria D, Roselli C, Benedetti X, Feduzi L (2015) Essential and toxic elements in honeys from a region of central Italy. J Toxicol Environ Health A 78:617-627. https://doi.org/ 10.1080/15287394.2014.1004006

43. Celechovská O, Vorlová L (2001) Groups of honey - physicochemical properties and heavy metals. Acta Vet 70:91-95

44. Toth T, Kopernicka M, Sabo R, Kopernicka T (2016) The evaluation of mercury in honey bees and their products from eastern Slovakia. Anim Sci Biotechnol 49:257-260

45. Toporcák J, Legáth J, Kulková J (1992) Levels of mercury in samples of bees and honey from areas with and without industrial contamination. Vet Med Praha 37:405-412

46. Maragou NC, Pavlidis G, Karasali H, Hatjina F (2016) Cold vapor atomic absorption and microwave digestion for the determination of mercury in honey, pollen, propolis and bees of Greek origin. Glob Nest J 18:690-696

47. Akbari B, Gharanfoli F, Khayyat MH, Khashyarmanesh Z, Rezaee R, Karimi G (2012) Determination of heavy metals in different honey brands from Iranian markets. Food Addit Contam 5:105-111

48. Jovetić MS, Redžepović AS, Nedić NM, Vojt D, Đurđić SZ, Brčeski ID, Milojković-Opsenica DM (2018) Urban honey - the aspects of its safety. Arh Hig Rada Toksikol 69:264-274

49. Idoko JO, Ijege KO, Haruna BS, Tifwa PA, Musa WO (2018) Evaluation of heavy metals in honey from Brinin-Gwari (Nigeria). J Chem Soc 43:99-103

50. Salama AS, Etorki AM, Awad MH (2019) Determination of physicochemical properties and toxic heavy metals levels in honey samples from West of Libya. J Adv Chem Sci 5:618-620

51. Kek SP, Chin NL, Tan SW, Yusof YA, Chua LS (2017) Classification of honey from its bee origin via chemical profiles and mineral content. Food Anal Methods 10:19-30

52. Chandrama S, Shubharani R, Sivaram V (2014) Assessment of heavy metals in honey by atomic absorption spectrometer. World J Pharm Pharmac Sci 3:509-515

53. Ru QM, Feng Q, He JZ (2013) Risk assessment of heavy metals in honey consumed in Zhejiang province, southeastern China. Food Chem Toxicol 53:256-262 
54. Bilandžić N, Đokić M, Sedak M, Varenina I, Kolanović BS, Končurat A, Šimić B, Rudan N (2012) Content of five trace elements in different honey types from Koprivnica-Kriżevci County. Slov Vet Res 49:167-175

55. Tariba Lovaković B, Lazarus M, Brčić Karačonji I, Jurica K, Živković Semren T, Lušić D, Brajenović N, Pelaić Z, Pizent A (2018) Multi-elemental composition and antioxidant properties of strawberry tree (Arbutus unedo L.) honey from the coastal region of Croatia: risk-benefit analysis. J Trace Elem Med Biol 45:85-92. https://doi.org/10.1016/j.jtemb.2017.09.022

Publisher's Note Springer Nature remains neutral with regard to jurisdictional claims in published maps and institutional affiliations. 